\title{
Purification and Characterization of an Antigen That Is Spatially Segregated in the Primary Olfactory Projection
}

\author{
James E. Schwob ${ }^{1}$ and David I. Gottlieb ${ }^{2}$ \\ 'Department of Anatomy and Cell Biology, SUNY Health Sciences Center at Syracuse, Syracuse, New York 13210, and \\ 2Department of Anatomy and Neurobiology, Washington University School of Medicine, St. Louis, Missouri 63110
}

\begin{abstract}
The monoclonal antibody RB-8 heavily labels axons from the ventrolateral olfactory epithelium and their terminals in the glomeruli of the ventrolateral olfactory bulb, but leaves the axons from the dorsomedial epithelium unstained or lightly stained. RB-8 reacts with a $125 \mathrm{kDa}$ membrane protein in both olfactory nerve and other parts of the CNS (Schwob and Gottlieb, 1986). Here we report further characterization of the molecular nature and cellular localization of the RB-8 antigen.
\end{abstract}

The RB-8 antigen is exposed on the surface of olfactory axons. Individual axons and axon bundles stain when explant cultures of the fetal olfactory epithelium are incubated with monoclonal RB-8 antibody while living. The cell membrane is demonstrably intact, and access to the cell interior is blocked under these conditions, since the living axons do not stain if exposed to an antibody against a known intracellular constituent.

The RB-8 antigen is an integral membrane protein. When assayed by direct radioimmunoassay (RIA), the antigen remains associated with brain membranes after extraction at pH 11, which solubilizes numerous other protein bands.

The 125 kDa RB-8 antigen was purified to homogeneity from whole rat brains by extracting membranes with sodium deoxycholate, immunoaffinity chromatography over an RB-8 antibody column, and preparative one-dimensional SDSPAGE. The $\mathrm{NH}_{2}$-terminal amino acid sequence is apparently unique among neuron-specific proteins that have been sequenced and has only an insignificant degree of homology with other known proteins.

Two polyclonal rabbit antisera raised against the purified antigen recognize only the $125 \mathrm{kDa}$ protein on immunoblots. Immunohistochemical staining of the primary olfactory projection with the antisera exactly matches that seen with monoclonal RB- 8 antibody. Thus, the RB- 8 antigens in brain and in olfactory nerve are highly homologous, if not identical. Furthermore, the results with the antisera suggest that the expression of the entire $125 \mathrm{kDa}$ protein is regulated differentially between ventral and dorsal zones of the olfactory epithelium.

Received Nov. 4, 1987; revised Feb. 11, 1988; accepted Feb. 12, 1988.

This work was supported by NIH Grants NS12867 (to D.I.G) and NIH Postdoctoral Fellowship NS08076 (to J.E.S.). The authors would like to thank Nuri B. Farber for his contribution to the early stages of this work and Dave McCourt for his assistance with the amino acid sequencing. They would also like to thank Dr. Karina F. Meiri for her advice during the course of these experiments and on the manuscript.

Correspondence should be addressed to Dr. Schwob at the above address.

Copyright (C) 1988 Society for Neuroscience $0270-6474 / 88 / 093470-11 \$ 02.00 / 0$
The additional characterization of the RB-8 antigen reported here places constraints on the potential functions of this protein. The availability of polyclonal antisera may prove useful in assessing the role of this spatially segregated antigen in the primary olfactory projection.

Olfactory stimuli are encoded by the olfactory sensory neurons, which in vertebrates reside in the olfactory epithelium lining the posterodorsal part of the nasal cavity. There is substantial evidence for a degree of spatial organization in olfactory sensory coding by the epithelium, which is maintained by the quadrantonto-quadrant axonal projection of the epithelium onto the glomeruli of the olfactory bulb. The evidence for a spatial component includes the finding of regional differences in the responsivity of the olfactory epithelium to a variety of odorants (Mozell, 1964; Thommesen and Doving, 1977; Lancet et al., 1981; Mackay-Sim et al., 1982), and of punctate, regionally restricted activation of the olfactory bulb by selected compounds (Adrian, 1953, 1954; Skeen, 1977; Thommesen, 1978; Stewart et al., 1979; Jourdan et al., 1980; Lancet et al., 1982).

Recently, we reported the isolation and characterization of a new monoclonal antibody, designated RB-8, that recognizes a biochemical difference between parts of the olfactory epithelium in rats. Immunoreactivity with the antibody divides the epithelium into 2 broad, nonoverlapping zones: the antigen is expressed by neurons of the ventrolateral epithelium (this zone is designated RB-8-positive), but is lacking in the complementary, dorsomedial part of the epithelium (termed RB- 8 negative) (Schwob and Gottlieb, 1986). The RB-8 antigen is found elsewhere in the CNS and PNS, but is restricted to the nervous system (Schwob and Gottlieb, 1986). Independently, Mori and coworkers described a monoclonal antibody, designated R4B12, that stains the rabbit primary olfactory projection in a fashion that is strikingly similar to the pattern in rats produced by $\mathrm{KB}-8$ (Fujita et al., 1985; Mori et al., 1985). Both RB-8 and R4B12, in rats and rabbits, respectivcly, intenscly label the axons from the ventrolateral olfactory epithelium, including their terminal portion in the glomeruli in the ventrolateral olfactory bulb; the olfactory axons and glomeruli in the dorsomedial zone stain poorly, if at all. Indeed, in both species the boundaries between the heavily stained zone of the epithelium and the unstained zone fall in very closely matched locations along the nasal septum and lurbinates.

The division of the olfactory projection into 2 spatially distinct zones may be functionally relevant in light of the evidence for a spatial component to olfactory coding already cited. However, the role of the RB-8 antigen at the cellular level has yet 
to be defined. We had shown in our previous report that the RB-8 antibody recognizes a membrane-associated protein of $125 \mathrm{kDa} M_{1}$ in both olfactory nerve and elsewhere in the brain (Schwob and Gottlieb, 1986). Nonetheless, many questions about the molecular nature and localization of this protein have not been answered.

Here, we report the further characterization of the $125 \mathrm{kDa}$ RB-8 antigen. These studies demonstrate that the epitope recognized by RB-8 is exposed on the external surface of olfactory axons in tissue culture, and that the antigen is an integral membrane glycoprotein. On the assumption that the antigen in the olfactory nerve is the same as that in the remainder of the CNS, the $125 \mathrm{kDa}$ protein was purified to homogeneity from whole brain. The $\mathrm{NH}_{2}$-terminal amino acid sequence was determined and found to be a novel sequence. Immunohistochemical staining with 2 independently generated polyclonal antisera prepared against the pure protein exactly replicates the staining pattern in the primary olfactory projection observed with the monoclonal RB-8 antibody. This result confirms our assumption that the $125 \mathrm{kDa}$ protein from olfactory nerve is, at the very least, highly homologous to the protein found elsewhere in the brain. Furthermore, the differential staining of the olfactory projection with the antisera suggests that the expression of the entire 125 $\mathrm{kDa}$ protein is restricted to ventral epithelium, and tends to rule out the alternative possibility that the staining pattern with the monoclonal antibody is due to the differential expression of a single epitope. This characterization of the RB- 8 antigen will allow it to be compared with other known or newly discovered neuron-specific cell surface antigens. A preliminary report of these results has previously been published (Schwob and Gottlieb, 1987).

\section{Materials and Methods}

Animals. For immunohistochemistry, 6-8-week-old outbred SpragueDawley rats obtained from a barrier-isolated facility (Sasco) were used. They were examined histologically for the presence of chronic rhinitis or epithelial atrophy and were found to be free of disease. Rat fetuses were from timed pregnancies, obtained commercially (Chappel Breeders). Two female white New Zealand rabbits (Boswell's Bunny Farm) were used for the preparation of polyclonal antisera.

Materials. All biochemical and immunochemical reagents were obtained from Sigma Chemical Co. and were reagent grade unless otherwise specified.

Monoclonal antibody production. The generation and characterization of the RB-8-producing hybridoma and the production of monoclonal antibody-containing ascites fluid were described previously (Schwob and Gottlieb, 1986). In addition, large volumes of RB-8-containing supernatants were collected from hybridoma cultures grown in Dulbecco's modified Eagle's media (DMEM) with 10\% fetal calf serum and $2 \mathrm{~mm}$ glutamine in order to provide a source of RB-8 immunoglobulin for purification that is uncontaminated by other mouse immunoglobulins.

Indirect light-microscopic immunohistochemistry. Immunohistochemical staining of tissue sections by the avidin-biotinylated HRP mcthod was pcrformed according to the prcedures detailed in Schwob et al. (1986) and Schwob and Gottlieb (1986).

\section{Olfactory epithelium in tissue culture}

Explant cultures of the fetal olfactory epithelium were prepared in a manner similar to that used by Gonzales et al. (1985). Rat fetuses were used from the 16th to the $18 \mathrm{th} \mathrm{d}$ of gestation (E16-E18). The dam was deeply anesthetized with sodium pentobarbital and the fetuses were then removed and decapitated. The nasal cavity was exposed by removing the palate to allow the nasal septum to be harvested. The mucosa was stripped from the upper one-half to two-thirds of the cartilage and diced into fragments of roughly $0.5 \mathrm{~mm}^{2}$. These fragments of olfactory mucosa were explanted onto poly-L-ornithine-coated glass coverslips in
DMEM supplemented with $20 \mathrm{~nm}$ progesterone, $5 \mu \mathrm{g} / \mathrm{ml}$ insulin, $10 \mu \mathrm{g}$ $\mathrm{ml}$ transferrin, $100 \mu \mathrm{M}$ putrescine, and $30 \mathrm{~nm}$ sodium selenite. The cultures were maintained at $37^{\circ} \mathrm{C}$ in a humidified, $7 \% \mathrm{CO}_{2}$ atmosphere

After 4-6 d in vitro, the living cultures were exposed to one of several antibodies. All of the steps were carried out at room temperature. The culture medium was carefully aspirated and replaced with DMEM buffered to $\mathrm{pH} 7.4$ with $25 \mathrm{mM}$ HEPES (tissue culture medium, TCM) that contained $5 \%$ filtered normal horse serum. The explants were incubated with this solution for 5 min to block nonspecific protein binding. The cultures were then treated for $45 \mathrm{~min}$ with the primary antibody in TCM with $20 \%$ normal horse serum. Either monoclonal antibody RB-8, at a 1:400 dilution, the monoclonal anti-vimentin antibody SBV-21 at 1:500 (Schwob et al., 1986), or nonimmune mouse serum was used. At the end of the primary incubation, the explants were washed once with TCM-5\% horse serum for $5 \mathrm{~min}$, rinsed rapidly in TCM, and fixed for $10 \mathrm{~min}$ in freshly prepared $2 \%$ paraformaldehyde in $0.1 \mathrm{M}$ phosphate buffer. After fixation, the cultures were rinsed twice in PBS and blocked again in PBS-5\% horse serum. Subsequent incubations with the biotinylated horse anti-mouse IgG secondary antibody and then with the avidin-biotinylated HRP complex or avidin-Texas red conjugate (Vector Laboratories) were conducted in the same way as for tissue sections (Schwob and Gottlieb, 1986; Schwob et al., 1986). The coverslips bearing the explants were attached to slides with buffered glycerin and examined under incident light (in the case of the HRP product) or epifluorescence (in the case of the Texas red conjugate) with a Leitz Ortholux microscope equipped with phase-contrast optics and a Leitz N2 filtcr.

\section{Biochemical characterization of the $R B-8$ antigen}

Protein amounts were determined by the bicinchoninic acid method (Pierce Chemical Co.) using BSA as the standard (Smith et al., 1985).

Membrane preparation. All steps were carried out at $0-4^{\circ} \mathrm{C}$ unless otherwise specified. Crude membranes prepared from whole brain, including the olfactory bulbs, were used as the starting material for the characterization and purification studies. Their preparation is described in detail in Schwob and Gottlieb (1986). In addition, some of the experiments utilized membranes harvested from scrapings of the olfactory nerve layer of the olfactory bulb or from the forebrain, excluding the olfactory bulbs. These were prepared according to the same protocol (Schwob and Gottlieb, 1986).

Direct radioimmunoassay (RIA). A direct RIA, based on the binding of ${ }^{125}$ I-RB-8 antibody to its antigen, was used to detect the RB-8 antigen and estimate its amount during the characterization and purification of the $125 \mathrm{kDa}$ protein. The membrane-bound RB- 8 antigen was assayed with a pellet assay according to the procedure of Schwob and Gottlieb (1986). There was one difference from the published methods describing the purification and iodination of the RB-8 antibody to be used in the RIA: the monoclonal RB-8 IgG was purified to homogeneity from hybridoma supernatant rather than from ascites fluid in order to eliminate any contaminating mouse immunoglobulins. Detergent extracts of brain membranes and eluates from the RB-8 affinity column (see below) containing soluble RB- 8 antigen were assayed by immobilizing the sample ( $25 \mu \mathrm{g}$ of protein or less) on to nitrocellulose paper (BA85; $0.45 \mu \mathrm{m}$ pore size; Schleicher and Schuell) via filtration, using a Minifold II dot blot apparatus (Schleicher and Schuell). The amount of protein used in the assay falls below the theoretical protein-binding capacity of the nitrocellulose paper (Monroe, 1985). The nitrocellulose paper was blocked for $45 \mathrm{~min}$ with a solution of $5 \%$ BSA-5\% nondairy creamer in $10 \mathrm{~mm}$ Tris $/ 50 \mathrm{~mm} \mathrm{NaCl}$ (Tris-saline) at $\mathrm{pH} 7.5$. Strips of nitrocellulose paper that included quadruplicate samples were incubated for $1 \mathrm{hr}$ with either radiolabeled RB-8 antibody alone, at a concentration of $500 \mathrm{ng} / \mathrm{ml}$ in blocking solution (which exceeds saturation) or with labeled antibody plus a 150 -fold excess of cold RB-8 antibody. The antibody concentrations are comparable to those used in the RIAs of the membrane-bound antigen. Subsequently, the strips were washed 3 times in Tris-saline with $1 \% \mathrm{BSA}$, and the individual wells were punched out and counted on a gamma counter. The difference between signal (labeled antibody alone) and nonspecific background (labeled antibody plus cold antibody) was at least 5-10 times background for the assay of nitrocellulose-bound antigen.

$S D S-P A G E$. Samples of whole-brain homogenates and of membrane preparations from the whole brain, the olfactory nerve, and the forebrain, excluding the olfactory bulbs, were solubilized directly by boiling in SDS-sample buffer containing $10 \mathrm{~mm}$ dithiothreitol. The proteins in samples of detergent extracts or affinity column eluates were first precipitated in chloroform-methanol (Wessel and Flugge, 1984) at room 
temperature before solubilization in hot sample buffer. The samples were run on $8 \%$ polyacrylamide gels in a Protean II mini-gel apparatus (Bio-Rad) following the method of Laemmli (1970).

Electrophoretic transfers and immunoblots. After separation by SDSPAGE, proteins were electrophoretically transferred to nitrocellulose paper at $150 \mathrm{~V}$ for 20 min using a Trans-Blot Cell (Bio-Rad) according to the method of Towbin et al. (1979). After transfer, the paper was rinsed in Tris-saline for $45 \mathrm{~min}$ and then blocked by incubation for 45 min with $5 \% \mathrm{BSA} / 5 \%$ nondairy creamer in Tris-saline. The blots were incubated for $1 \mathrm{hr}$ with the primary antibody at the following dilutions in the blocking solution. Pure RB- 8 IgG was used at $1.5 \mu \mathrm{g} / \mathrm{ml}$. Polyclonal rabbit antiserum generated against the purified $125 \mathrm{kDa} \mathrm{KB}-8$ antigen was used at a dilution of 1:800 or greater. Nonspecific binding was assessed by incubating the nitrocellulose paper in nonimmune mouse serum at a 1:1000 dilution, while preimmune serum was used at a concentration of $1: 800$ or greater to match the dilution of the immune serum. The rest of the steps, using biotinylated secondary antibody and the avidin-biotinylated HRP complex, were carried out according to published procedure (Schwob and Gottlieb, 1986).

High pH extraction. Whole-brain membranes were extracted at high $\mathrm{pH}$ in a manner similar to that used by Burden et al. (1983). Frozen membranes were thawed and centrifuged for 4,000,000 $\mathrm{g}$-min. One aliquot was resuspended in Tris-saline at $4^{\circ} \mathrm{C}$ to its original volume and remained on ice. The other 2 aliquots were resuspended in cold $\mathrm{H}_{2} \mathrm{O}$ at a protein concentration of $0.5 \mathrm{mg} / \mathrm{ml}$, which resulted in a $\mathrm{pH}$ of 7.5 . the $\mathrm{pH}$ of one of these was adjusted to 11 with $\mathrm{NaOH}$ and then stirred on ice for $1 \mathrm{hr}$. At the end of the hour, the base-washed and $\mathrm{H}_{2} \mathrm{O}$-washed membranes were separated from any solubilized proteins by centrifugation for 4,000,000 g-min. The membrane pellets were then resuspended to their original volume in Tris-saline. These samples, and a sample of the membranes directly resuspended in Tris-saline, were assayed for the presence of membrane-bound RB-8 antigen by using the direct RIA described previously (Schwob and Gottlieb, 1986; see abovc).

\section{Purification of the $R B-8$ antigen}

Extraction of the antigen with deoxycholate. Whole-brain membranes were thawed and centrifuged for 4,000,000 $\mathrm{g}$-min. The resulting pellet was resuspended by sonication to a protein concentration of $10 \mathrm{mg} / \mathrm{ml}$ in a solution of $1 \%$ sodium deoxycholate (DOC) in $10 \mathrm{~mm}$ Tris at pH 8.0 with $5 \mathrm{~mm}$ EDTA, $2 \mathrm{~mm}$ phenylmethylsulfonyl fluoride (PMSF), $14 \mu \mathrm{M}$ leupeptin, $40 \mu \mathrm{M}$ pepstatin A, and $50 \mu \mathrm{g} / \mathrm{ml}$ aprotinin. The solution was stirred on ice for $1 \mathrm{hr}$. Detergent-solubilized material was separated from the extracted membranes by centrifugation for $5,200,000$ $g$-min and stored at $-70^{\circ} \mathrm{C}$ until used. The soluble-phase direct RIA was used to assess the proportion of the antigen remaining in the DOCextracted membranes by resuspending the pellet to its original volume with Tris-saline. An aliquot of membranes that had been centrifuged and resuspended in Tris-saline rather than detergent served as the control sample. Similarly, the detergent supernatant was assayed for the presence of the antigen by applying the direct RIA to proteins immobilized on nitrocellulose, as described above.

Immunoaffinity chromatography. An RB-8 immunoaffinity column was constructed as follows: The IgG in RB-8 ascites was precipitated by addition of saturated ammonium sulfate, which enriched IgG to approximately $70 \%$ of total protein. The protein concentration was adjusted to $13 \mathrm{mg} / \mathrm{ml}$ with $0.1 \mathrm{M} 3-(\mathrm{N}$-morpholino)propanesulfonic acid (MOPS) at pH 7.5. The RB-8 IgG preparation was coupled to an AffGel 10 matrix (Bio-Rad) according to the manufacturer's instructions at a ratio of $10 \mathrm{mg}$ protein $/ \mathrm{ml}$ coupled beads.

The RB- 8 column was incubated in suspension with the DOC-extracted material for $2 \mathrm{hr}$ in the cold room. Subsequently, the column was washed with a total of 50 column volumes of $10 \mathrm{~mm}$ Tris- $300 \mathrm{~mm}$ $\mathrm{NaCl}-1 \%$ DOC at $\mathrm{pH} 8.0$. Bound protein was eluted with 3 column volumes of $0.1 \mathrm{~m}$ diethylamine-1\% DOC at $\mathrm{pH} 11$. The eluate was brought to $\mathrm{pH} 8.0$ by addition of $1 \mathrm{M}$ Tris- $\mathrm{HCl}$, and the volume of the eluate was reduccd using a Ccntriprep concentrator (Amicon). One column run utilized approximately $1.5 \mathrm{gm}$ of whole brain (wet weight) $/ \mathrm{ml}$ of column matrix.

The disappearance of the RB- 8 antigen from the detergent-extracted material during affinity chromatography and its subsequent appearance in the column eluate were documented by the use of SDS-PAGE immunoblots and direct RIA on nitrocellulose-immobilized samples of pre- and postcolumn DOC extracts and of the column eluate

Purification by preparative 1 -dimensional SDS-PAGE. The final pu- rification of the $125 \mathrm{kDa}$ band to homogeneity was accomplished through separation of the proteins in the RB-8 affinity column eluate by 1 -dimensional preparative SDS-PAGE on 3-mm-thick $9 \%$ polyacrylamide slab gels that were $11 \mathrm{~cm}$ long $\times 14.5 \mathrm{~cm}$ wide. Approximately $2.5 \mathrm{mg}$ of eluted protein, containing about $500 \mu \mathrm{g}$ of $125 \mathrm{kDa} \mathrm{RB}-8$ antigen, was precipitated with chloroform-methanol, resolubilized in SDS-sample buffer, and loaded on the gel. The gel was run for 1000 $\mathrm{V}$-hr. The $125 \mathrm{kDa}$ band, the most prominent protein in the column eluate by far, was visualized in one of 2 ways. Either the gel was incubated with $4 \mathrm{M}$ sodium acetate for $20 \mathrm{~min}$ to produce a negative image of the band when the gel was illuminated at an oblique angle, or the gel was lightly stained with Coomassie blue in order to visualize the 125 $\mathrm{kDa}$ band. The polyacrylamide gel was then diced and homogenized in about 40 volumes of $0.1 \mathrm{M}$ Tris acetate- $0.1 \%$ SDS using a glass-on-glass Ten Broeck tissue grinder. The protein was allowed to diffuse out of the fragmented gel in suspension for $2 \mathrm{hr}$ and then separated from the gel by centrifugation for 4,000,000 $\mathrm{g}$-min. The supernatant was decanted, lyophilized, and resuspended in $\mathrm{H}_{2} \mathrm{O}$ at an approximate concentration of $80 \mu \mathrm{g}$ of protein $/ \mathrm{ml}$. The purity of the diffusion-eluted samples was confirmed by analytical SDS-PAGE (Fig. 2) and they were stored at $-70^{\circ} \mathrm{C}$ before being used for sequence analysis or immunization.

Lectin blots. Samples of the gel-purified $25 \mathrm{kDa}$ RB- 8 antigen were subjected to SDS-PAGE, transferred to nitrocellulose, and then probed for reactivity with several lectins. After transfer, the nitrocellulose paper was blocked with Tris-saline-10\% BSA for $30 \mathrm{~min}$ and then incubated with biotinylated lectin in blocking solution for $1 \mathrm{hr}$. Soybean agglutinin and lectins from Helix pomatia and Ricinus communis were used at 5 $\mu \mathrm{g} / \mathrm{ml}$, concanavalin A at $3 \mu \mathrm{g} / \mathrm{ml}$, and WGA at $2 \mu \mathrm{g} / \mathrm{ml}$ plus $0.5 \mathbf{~ M}$ $\mathrm{NaCl}$. The nitrocellulose strips were washed 3 times, incubated with the avidin-biotinylated HRP complex, and reacted with DAB as for the immunoblots. As a control for nonspecific binding of the lectin, the relevant monosaccharide ligand was added at $1 \mathrm{~m}$ : for Helix pomatia and soybean agglutinin, $\mathrm{N}$-acetyl galactosamine; for Ricinus communis, galactose; for concanavalin A, $\alpha$-methyl mannoside; and for WGA, $\mathrm{N}$-acetyl glucosamine.

\section{$\mathrm{NH}_{2}$-terminal amino acid sequence analysis}

$\mathrm{NH}_{2}$-terminal amino acid sequence analysis was performed on a Beckman gas-phase sequenator. The sample was spin-filtered over G-25 Sephadex (Tuszynski et al., 1980) and precipitated with 4 volumes of acetone at $-20^{\circ} \mathrm{C}$. The pellet was solubilized in $88 \%$ formic acid immediately before it was spotted on a polybrenc-coatcd glass filter and loaded on the sequenator. Phenylthiohydantoin (PTH) amino acids were identified by high-performance liquid chromatography (HPLC) over a $22 \mathrm{~cm} \times 2.1 \mathrm{~mm}$ microbore PTH $\mathrm{C}_{18}$ column (Applied Bio-Systems). A total of 200-300 pmol of antigen were sequenced per run. Three different preparations of the $125 \mathrm{kDa}$ RB- 8 antigen were sequenced.

\section{Preparation of polyclonal antiserum}

Two rabbits were used to prepare the polyclonal antisera. One rabbit was immunized 6 times over a 6 month period. The second was immunized twice, the procedures being separated by 6 weeks. Each time, approximately $100 \mu \mathrm{g}$ of the $125 \mathrm{kDa}$ RB-8 antigen was injected intradermally. The immunogen was prepared by chloroform-methanol precipitation of the gel-purified protein and resuspension of the pellet in sterile saline containing $0.25 \mathrm{mg}$ monophosphoryl lipid A and $0.25 \mathrm{mg}$ trehalose dimycolate as adjuvants (MPL-TDM adjuvant; RIBI ImmunoChem Research). Samples of preimmune and immune blood were collected from the central ear vein by venipuncture. At the end of the immunization regimen, the animal was deeply anesthetized with an overdose of sodium pentobarbital and then exsanguinated by arterial and cardiac puncture. After the blood had clotted, the serum was separated from the clot by centrifugation at $60,000 \times \mathrm{g} / \mathrm{min}$, snap-frozen in liquid $\mathrm{N}_{2}$, and stored at $-70^{\circ} \mathrm{C}$.

\section{Results}

The following questions were addressed in order to characterize the RB-8 antigen more fully: (1) Is it disposed as a cell surface or as an internal antigen? (2) Is it an integral membrane protein? (3) Is it a novel protein at the sequence level? (4) Is it a glycoprotein? (5) Does a polyclonal antiserum generated against the purified $125 \mathrm{kDa}$ protein from brain reveal the same differential 
distribution of the antigen in the olfactory bulb as is shown by the monoclonal antibody? The results in relation to each of these questions will be described in turn.

\section{The RB-8 antigen is found on the cell surface of olfactory} axons

The cell surface localization of the RB-8 antigen was demonstrated by incubating living cultures with the monoclonal RB-8 antibody. In living cells, the plasma membrane serves as a diffusion barrier, preventing access of immunoglobulins and other proteins to internally disposed antigens. After 4-6 d in vitro, living explants of fetal olfactory epithelium were labeled with monoclonal RB-8 antibody and then fixed prior to immunoflourescent visualization of the bound antibody. The axonal plexus is stained with the antibody and the staining extends well out toward the tips of the neurites before the fluorescent intensity becomes too low to detect reliably (Fig. 1A). The stained fiber bundles consist of a large number of labeled axons. Individual axons, which can be recognized by phase microscopy, are also stained (Fig. 1, B,C). For the particular explant illustrated in Figure 1, every axon that could be identified as an isolated fiber or as one fiber among a small number in a bundle was stained. The possibility that a few axons remain unstained but are hidden within an intensely labeled bundle cannot be excluded. There was variation in the intensity of the staining between different cxplants, but no attempt was made to segregate explant cultures of dorsal, presumptively RB-8-negative epithelium, from ventral, RB-8-positive epithelium.

The binding of antibody to living axons indicates that the RB-8 antigen is exposed on the cell surface. Two controls were employed. The first entailed treating parallel explant cultures with an equivalent concentration of nonimmune mouse serum or another monoclonal antibody that did not bind to intact axons. No staining was seen under these conditions, which rules out nonspecific binding of the immunoglobulin as the cause for the labeling of living axons with RB-8. The second control exposed living explants to monoclonal antibody SBV-21, directed against the intermediate filament protein vimentin; vimentin is found within olfactory axons (Schwob et al., 1986). When the explant was fixed and permeabilized prior to addition of SBV21 to the medium, explant-derived axons, as well as fibroblasts in the culture, were labeled with the anti-vimentin monoclonal antibody (not shown). Thus, olfactory axons in vitro, as well as in vivo, contain vimentin or a highly vimentin-like protein. In contrast, explants that were incubated with anti-vimentin antibody while living showed no staining, either of axons or fibroblasts (not shown). Since a known internal antigen is not exposed to the external milieu under these conditions, we conclude that the axonal membrane is not artifactually disrupted by the experimental procedure. Thus, the staining of living olfactory axons with RB-8 antibody is a valid demonstration that the RB-8 antigen is exposed on the cell surface.

\section{The $R B-8$ antigen is an integral membrane protein}

A membrane-associated protein is generally held to be integral to the membrane rather than peripherally bound if the protein is retained by the membranes after they have been washed with base (Steck and Yu, 1973; Burden et al., 1983; Wiedenmann et al., 1985). By this criterion, the RB-8 antigen is an integral membrane protein, since it remains associated with membranes despite prolonged washing at $\mathrm{pH} 11$, as detected with a direct RIA.
Whole-brain membranes treated for $1 \mathrm{hr}$ on ice at $\mathrm{pH} 11$ retain $99 \%$ of the antigen-binding sites present in control membranes that are washed in Tris-saline alone before assaying (Table 1). Membranes washed with $\mathrm{H}_{2} \mathrm{O}$ alone (which results in a measured $\mathrm{pH}$ of 7.5) retain roughly $91 \%$ of the control amount. SDS-PAGE of the base-washed, Tris-saline-washed, and $\mathrm{H}_{2} \mathrm{O}-$ washed pellets and of the base-washed supernatant, demonstrates that washing the membranes at $\mathrm{pH} 11$ releases a broad array of proteins into the supernatant, with a consequent reduction in the prominence of these bands in the base-washed pellet (data not shown). This includes the complete disappearance from the membrane pellet of a prominent doublet of proteins at about 240 and $250 \mathrm{kDa} M_{\mathrm{r}}$, which most likely represents fodrin (brain spectrin), a known peripheral membrane protein (Levine and Willard, 1981; Bennett, 1985), and the subsequent appearance of this doublet in the base-washed supernatant. These findings provide substantial evidence that the RB- 8 antigen is an integral membrane protein.

\section{The purification of the $125 \mathrm{kDa} R B-8$ antigen}

Because of the difficulty of collecting a large enough mass of olfactory nerve from which to purify a useful quantity of the $125 \mathrm{kDa}$ RB-8 antigen, the antigen was purified from whole brain on the assumption that it was the same as in the olfactory nerve. Support for this assumption comes from our previous observation that the immunoreactive proteins in olfactory nerve membranes and the membranes from the rest of the brain are $125 \mathrm{kDa} M_{\mathrm{r}}$ bands that comigrate on SDS-PAGF, when mixed together (Schwob and Gottlieb, 1986). A similar result is obtained when membrane proteins from olfactory nerve or forebrain are separated in the first dimension by isoelectric focusing and in the second dimension by SDS-PAGE performed according to the method of O'Farrell (1975). For each type of membrane preparation, Western blots of the 2-dimensional gels demonstrate several immunoreactive spots at $125 \mathrm{kDa}$, with pIs ranging from 6.2 to 6.8 . These spots are closely overlapping in gels loaded both with olfactory nerve and forebrain membranes as a single mixed sample (not shown). Additional support for this assumption derives from our demonstration that 2 polyclonal antisera raised against the $125 \mathrm{kDa}$ protein from whole brain replicate the pattern of staining in the primary olfactory projection seen with monoclonal RB-8 antibody (see below; Fig. 5). Like monoclonal RB-8 antibody, the polyclonal antisera recognize a $125 \mathrm{kDa}$ protein both in forebrain that was harvested without the olfactory bulb and in the olfactory nerve (see below).

The purification protocol entails the preparation of washed membranes from whole-brain homogenates, extraction of the RB-8 antigen from the membranes with DOC, enrichment of the antigen by passage over an RB- 8 immunoaffinity column, and separation of the $125 \mathrm{kDa}$ antigen from other proteins in the column eluate by preparative SDS-PAGE.

In whole-brain membranes, antigen-binding sites are present at $2.6 \mathrm{pmol}$ of antibody bound $/ \mathrm{mg}$ of membrane protein (Table 2). Assuming 1:1 binding of antibody to antigen, the RB-8 antigen is estimated as $0.03 \%$ of total membrane protein. Upwards of $85 \%$ of the antigen-binding sites can be extracted by incubating the membranes for $1 \mathrm{hr}$ in the cold with $1 \%$ DOC at a protein:detergent ratio of $12 \mathrm{mg} / \mathrm{ml}$ of detergent solution (Tablc 2). Increasing concentrations of DOC detergent or decreasing protein:detergent ratios have little or no effect on the percentage of antigen-binding sites released from the membranes. Nonionic detergents, including octylglucoside, Triton X-100, and NP-40. 

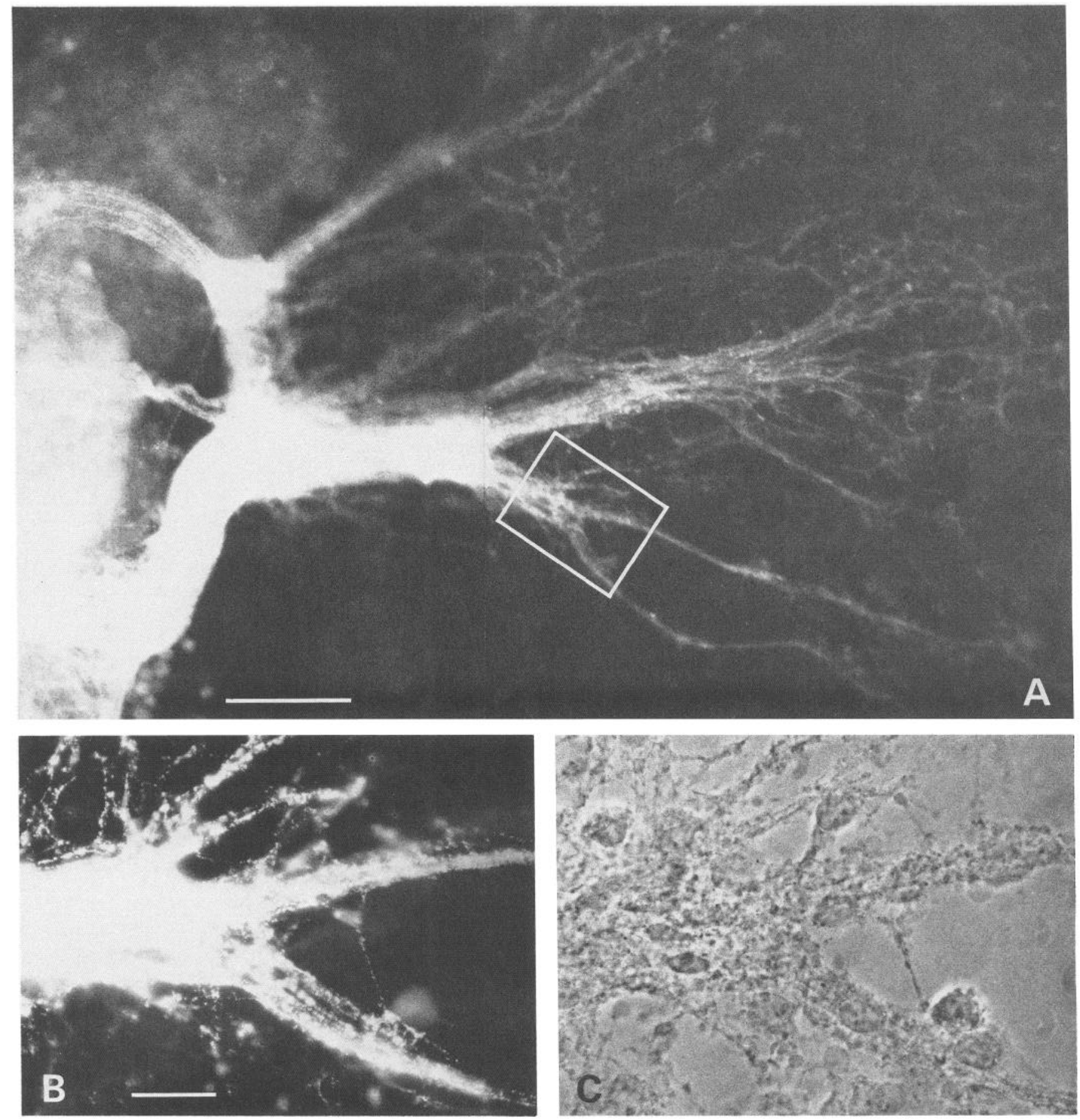

Figure 1. The RB-8 antigen is exposed on the cell surface. A, After $6 \mathrm{~d}$ in vitro, this explant of E16 olfactory epithelium (the explant is at the left edge of the fluorescence photomicrograph) was incubated, while still living, in tissue culture media containing monoclonal RB-8 antibody, washed, and then fixed. Bound antibody was visualized with biotinylated horse anti-mouse IgG antibody and avidin conjugated with Texas red. Since RB-8 binds to these living axons and the cell membrane remains intact under these conditions, the RB- 8 antigen is most likely exposed on the cell surface. $B$, Boxed area in $A$ shown at higher power. Compared to the phase-contrast photomicrograph of this field $(C)$, most, if not all, of the axon bundles and individual axons are stained. Scale bars: $100 \mu \mathrm{m}(A) ; 20 \mu \mathrm{m}(B)$.

extract proportionally less of the antigen and are optimal at lower protein:detergent ratios. The antigen is probably somewhat enriched by this step, since $85 \%$ of the binding sites are extracted by DOC as compared to $54 \%$ of the total membrane protein, which corresponds to a relative enrichment of 1.6.

Intact antigen can be recovered from the detergent superna- tant in a form that is recognized by the monoclonal RB-8 antibody. Immunoblots demonstrate the presence of the immunoreactive $125 \mathrm{kDa}$ protein in the detergent supernatant (Fig. 12 , section $\mathrm{B}$, lane 3 ). Likewise, radiolabeled RB-8 antibody will bind specifically to antigen after immobilization of the extracted proteins by filtration onto nitrocellulose paper. 
Table 1. pH 11 Extraction of brain membranes: effect on RB-8 antigen

\begin{tabular}{lcccc} 
& & & $\begin{array}{l}\text { Specific } \\
\text { binding } \\
\text { (\% of } \\
\text { control) }\end{array}$ & $\begin{array}{l}\text { Residual } \\
\text { RB-8 } \\
\text { antigen } \\
\text { (pmol/mg) }\end{array}$ \\
\hline Control membranes & $347,530 \pm 8829$ & $17,365 \pm 1522$ & 330,165 & 2.50 \\
Base-washed membranes & $348,893 \pm 5173$ & $22,652 \pm 2800$ & $\begin{array}{l}(100) \\
326,241 \\
(\text { mean } \mathrm{cpm} \pm \mathrm{SD})\end{array}$ & 2.47 \\
$\mathrm{H}_{2} \mathrm{O}$-washed membranes & $322,244 \pm 5597$ & $21,665 \pm 2311$ & $\begin{array}{l}(900,579 \\
(91)\end{array}$ & 2.28
\end{tabular}

The presence of the RB-8 antigen was assayed using a direct RIA on whole-brain membranes that were incubated for $1 \mathrm{hr}$ in Tris-saline (control membranes), water $\left(\mathrm{H}_{2} \mathrm{O}\right.$-washed), or water with the $\mathrm{pH}$ of the mixture adjusted to 11 (basewashed), as described in Materials and Methods. For each of the 3 conditions, aliquots of treated membranes corresponding to $100 \mu \mathrm{g}$ of protein prior to treatment were used. Labeled RB-8 antibody was added at a saturating concentration of $3.3 \times 10^{-9} \mathrm{M}$ alone $\left(8.5 \times 10^{5} \mathrm{cpm}\right.$ was added to each tube at a specific activity of $\left.1.28 \times 10^{6} \mathrm{cpm} / \mathrm{pmol}\right)$ to determine total binding ( ${ }^{125}$ I-RB-8 alone). Nonspecific binding was determined by incubation in the presence of excess unlabeled RB-8 ascites at a concentration of antibody equivalent to $5 \times 10^{-7} \mathrm{M}(+\mathrm{RB}-8)$. Nonspecific binding was subtracted from total binding to give the specifically bound counts. Each condition was assayed in triplicate.

The $125 \mathrm{kDa}$ RB-8 antigen is markedly enriched by chromatography over an immunoaffinity column constructed of monoclonal RB-8 antibody covalently bound to an Affi-Gel 10 matrix. As shown by SDS-PAGE, a protein at $125 \mathrm{kDa} M_{\text {, is }}$ by far the dominant band in the eluate from the RB-8 antibody column and thus is markedly enriched over the starting material (Fig. 2, section A, lane 4). That this band is the RB-8 antigen was further shown in two ways. First, the band at $125 \mathrm{kDa}$ was intensely labeled by monoclonal RB-8 antibody in immunoblots of the column eluate (Fig. 2, section B, lane 4). The presence of other immunoreactive bands in the column eluate will be discussed at the end of this section. Second, immunological manipulations demonstrated that enrichment of the $125 \mathrm{kDa}$ band depended on the interaction of the RB-8 antibody with the RB-8 antigen and could be blocked if either antigen or antibody was disrupted. The $125 \mathrm{kDa}$ band was not enriched by passage over a neutral antibody column constructed with monoclonal antibody $224-1 \Lambda 6-\Lambda 1$, which is directcd against chick N-CAM and does not bind to any rat proteins (Lemmon et al., 1982) (data not shown). Likewise, markedly less antigen was recovered from the detergent extract when the extract was incubated in solution with monoclonal RB-8 antibody before it was passed over the RB-8 antibody column; in the presence of soluble RB- 8 antibody, recovery of the antigen from the column was decreased to $16 \%$ of that seen in the presence of a neutral soluble antibody, based on RIA of the respective column eluates immobilized by filtration on nitrocellulose.
The final stage in the purification of the $125 \mathrm{kDa}$ antigen is preparative 1-dimensional SDS-PAGE. This step was chosen because no contaminating proteins are apparent in the $125 \mathrm{kDa}$ band when it is analyzed on 2-dimensional gels. Although the $125 \mathrm{kDa}$ band from the column eluate contain several protein spots with pIs of 6.2-6.8, as shown by silver stains of the isoelectric focusing (IEF)/SDS-polyacrylamide gels, all of the spots match up precisely with the immunoreactive spots on Western blots of parallel 2-dimensional gels. No nonimmunoreactive proteins are seen within the range of pIs (4.8-8.0) separated on the IEF/SDS-polyacrylamide gels or with nonequilibrium pH gel electrophoresis (NEPHGE)/SDS-PAGE encompassing the full range of pIs (data not shown). Accordingly, the proteins in the column eluate are separated by electrophoresis in $9 \%$ polyacrylamide-SDS slab gels. The $125 \mathrm{kDa}$ protein is released from the excised homogenized gel band by diffusion. SDS-PAGE of this gel-purified protein shows only a single band with Coomassie blue stain (Fig. 2, section A, lane 5), silver stain (not shown), or RB-8 immunoblots (Fig. 2, section B, lane 5). There is a faint protein smear immediately below the $125 \mathrm{kDa}$ band that most likely represents breakdown of the protein, since it is recognized by the RB-8 antibody (Fig. 2, section B, lane $5)$. This preparation is termed the pure $125 \mathrm{kDa}$ antigen and was used for the determination of amino acid sequence and for the generation of a polyclonal antiserum.

The immunoblot of the RB-8 column eluate also demonstrates an immunoreactive protein band at $94 \mathrm{kDa} M_{\mathrm{r}}$ that cor-

Table 2. Detergent solubilization of RB-8 antigen

$\begin{array}{lllll} & & & \begin{array}{l}\text { Specific } \\ \text { binding } \\ \text { (\% of } \\ \text { control) }\end{array} & \begin{array}{l}\text { Residual } \\ \text { RB-8 } \\ \text { antigen } \\ \text { (pmol/mg) }\end{array} \\ & \begin{array}{l}\text { 125I-RB-8 alone } \\ \text { (mean cpm } \pm \text { SD) }\end{array} & + \text { RB-8 } & \begin{array}{l}271,629 \\ (100)\end{array} & 2.62 \\ \text { Control membranes } & 292,734 \pm 2844 & 21,105 \pm 1283 & 40,671 & 0.39 \\ \text { DOC-extracted membranes } & 60,547 \pm 1318 & 19,876 \pm 287 & (15) & \end{array}$

The presence of the RB-8 antigen in brain membranes incubated with Tris-saline (control membranes) or in those extracted with $1 \%$ DOC on ice for $1 \mathrm{hr}$ (DOC-extracted) was determined as described in Materials and Methods. For each of the conditions, aliquots of membranes corresponding to $100 \mu \mathrm{g}$ of protein prior to treatment were assayed. Total ( ${ }^{125} \mathrm{I}-\mathrm{RB}-8$ alone), nonspecific (+RB-8), and specific bindings were determined as for Table 1 . 


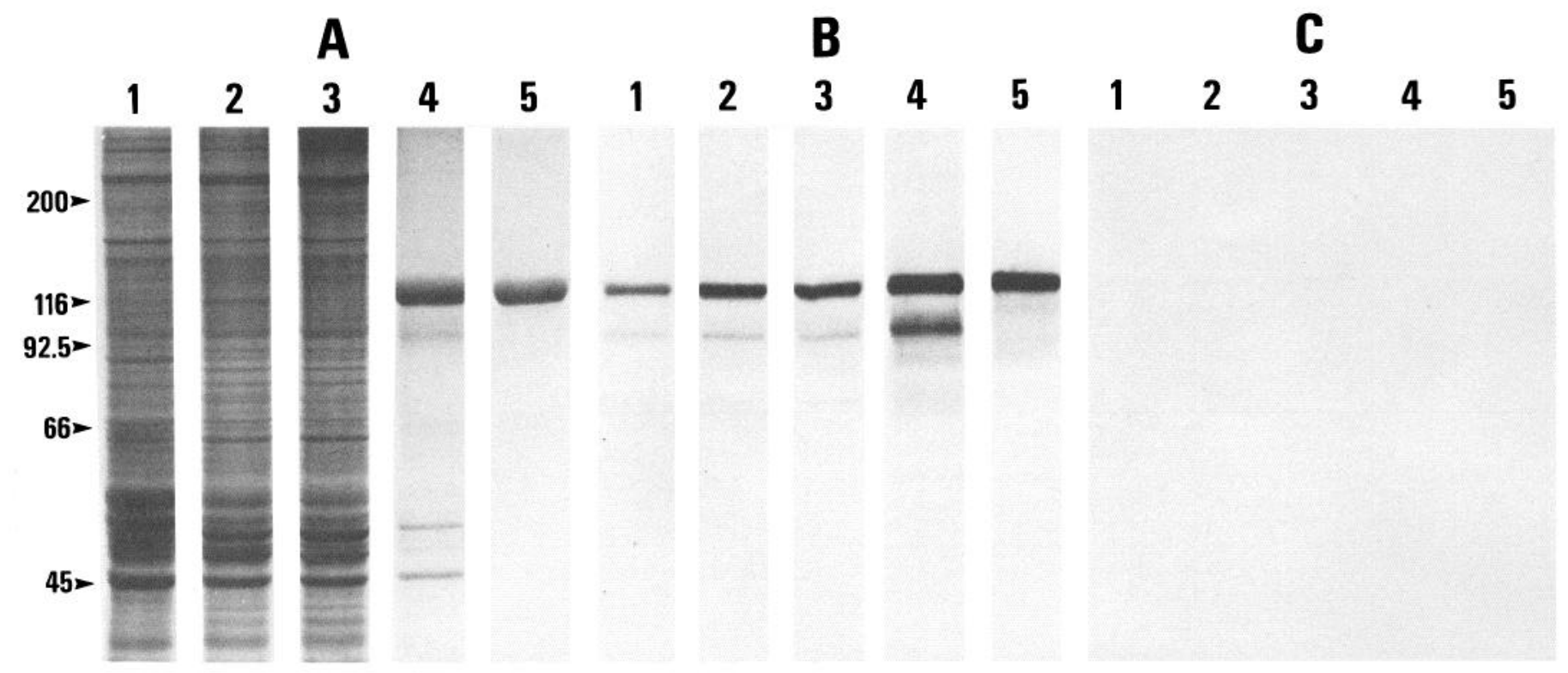

Figure 2. SDS-PAGE and immunoblots demonstrating the purification of the RB-8 antigen to homogeneity using a combination of immunoaffinity chromatography and preparative SDS-PAGE. $A$, Coomassie blue-stained gel. $B$, Western blot incubated with RB-8 monoclonal antibody. $C$, Western blot incubated with an equivalent concentration of nonimmune mouse serum. Lanes 1, Whole-brain homogenate; 2, whole-brain membranes; 3 , proteins extracted from membranes by incubation with deoxycholate (DOC) detergent. Each of lanes $1-3$ was loaded with about $25 \mu \mathrm{g}$ of protein. 4. Eluate from RB-8 immunoaffinity column. The protein at $125 \mathrm{kDa}$, which is the predominant species in the column eluate, is purified by electrophoresing the column eluate on a preparative SDA-PAGE gel, cutting the band out of the gel, and allowing the $125 \mathrm{kDa}$ protein to diffuse out of the ground-up gel band. 5, Gel-purified $125 \mathrm{kDa}$ protein. It is apparent from examination of the immunoblots that this $125 \mathrm{kDa}$ protein is the major immunoreactive species. However, an additional immunoreactive band is seen at $94 \mathrm{kDa}$ at all stages of the purification, from the brain homogenate (where it is very faint) to the column eluate. In the column eluate there are some additional, very faint, immunoreactive bands at several molecular weights less than $94 \mathrm{kDa}$. Molecular weight standards: myosin, $200 \mathrm{kDa}$; $\beta$-galactosidase, $116 \mathrm{kDa}$; phosphorylase B, $92.5 \mathrm{kDa}$; BSA, $66.2 \mathrm{kDa}$; ovalbumin, $45 \mathrm{kDa}$.

responds to a faint band in the Coomassie-stained gel and several fainter immunoreactive bands. The exact relationship of the $94 \mathrm{kDa}$ band to the $125 \mathrm{kDa} \mathrm{RB}-8$ antigen remains unclear. Comparison of the 2 bands on immunoblots or Coomassie-stained gel suggests that the $94 \mathrm{kDa}$ protein is a minor component in comparison to the $125 \mathrm{kDa}$ protein (Fig. 2). Proteolysis or deglycosylation of the $125 \mathrm{kDa}$ protein during purification is unlikely to be the sole explanation for the appearance of this other band, because it is present, albeit very faint, in brain homogenized directly into hot sample buffer containing SDS and at subsequent stages of the purification (Fig. 2, section B). Similarly, this band is not preferentially generated by proteolysis of the pure $125 \mathrm{kDa}$ protein with trypsin, chymotrypsin, V8 protease, or thermolysin, nor by deglycosylation with $\mathrm{N}$-glycanase (data not shown). Hence the $94 \mathrm{kDa}$ band may represent a product generated by processing of the $125 \mathrm{kDa}$ protein in the animal by a specific proteolytic step, a related protein generated by alternative splicing of a single mRNA, or a distinct protein that shares the RB-8 epitope. It should be noted that the 94 $\mathrm{kDa}$ band is also present in immunoblots of the olfactory nerve; it is much fainter than the $125 \mathrm{kDa}$ band here as well (data not shown). A clearer understanding of the relationship between these 2 proteins awaits further analysis.

\section{The N-terminal amino acid sequence of the $125 \mathrm{kDa} R B-8$ antigen}

The N-terminal amino acid sequence of the $125 \mathrm{kDa}$ RB- 8 antigen was analyzed for 3 separate gel-purified preparations on a gas-phase sequenator using Edman degradation and HPLC analysis of PTH-derivatized amino acids. The sequence could be determined with good yield through the seventeenth residue for 2 of the preparations and through the eighth residue in the third. The sequence, which is identical (where determinable) in all runs, is as follows:

\section{Leu-Leu-?-Val-Thr-Ile-Ser-Leu-Ser- Lys-Val-Glu-Leu-Ser-Val-Gly-Glu.}

The amino acid at the third position is indeterminate. Release of the antigen by homogenization of the gel and diffusion of the protein produces an artifact in the hydrophilic end of the PTHamino acid spectrum. This obscures the region near PTH-glutamine through the first few cycles of the sequencing run. It is possible that the peak corresponding to the derivatized third residue amino acid is buried within this artifact. The partial sequence of the RB-8 antigen was compared with other proteins in the Protein Sequence Data Base, Release 12.0 (National Biomedical Research Foundation, Washington, DC). The sequence appears to be novel, since no degree of homology greater than $44 \%$ ( 9 mismatches out of 16 residues) was found with any of the proteins reported in the data bank.

\section{The RB-8 antigen is a glycoprotein}

Purified antigen was electrophoresed on SDS-polyacrylamide gels, transferred to nitrocellulose, and probed with biotinylated concanavalin A and WGA. Both of these lectins bound to the $125 \mathrm{kDa}$ band when presented alone, but failed to bind to the protein in the presence of their respective monosaccharide ligands at a concentration of $1 \mathrm{M}$ (Fig. 3). Hence the lectin binding is specific and indicates that the $125 \mathrm{kDa}$ antigen is a glycoprotein. Biotinylated soybean agglutinin, biotinylated lectin from 


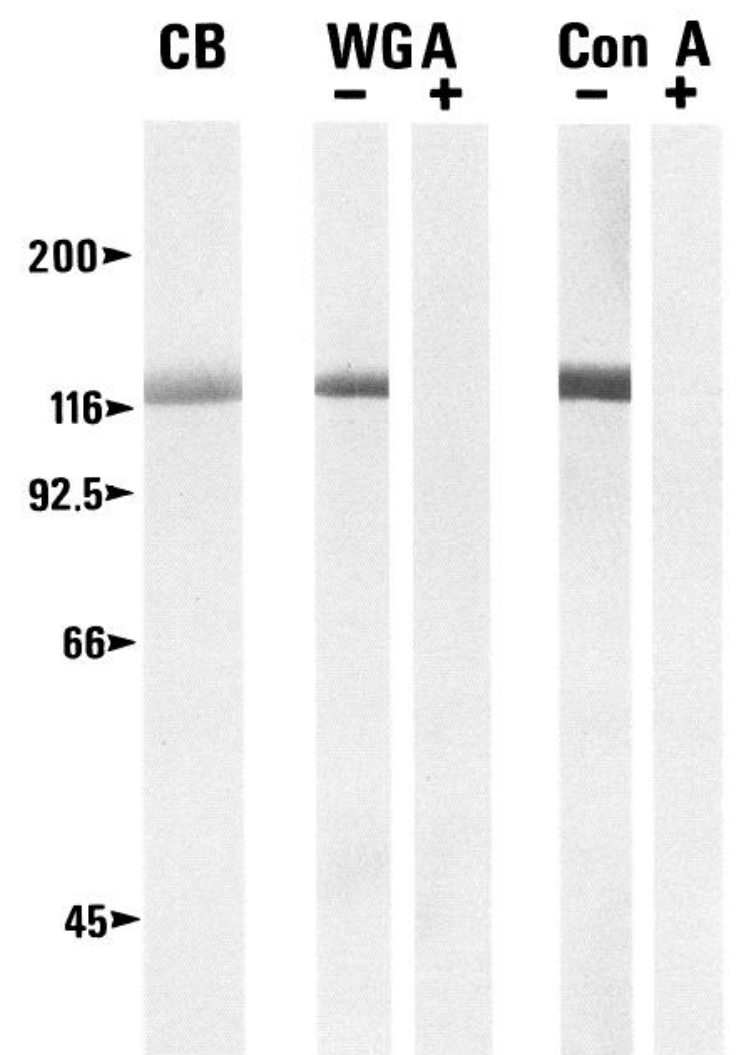

Figure 3. The RB-8 antigen is a glycoprotein. The antigen was purified by immunoaffinity chromatography and preparative 1-dimensional SDSPAGE, according to the protocol illustrated in Figure 2, run on a second SDS-PAGE gel, transferred to nitrocellulose, and reacted with biotinylated lectins. Bound lectin was visualized with avidin complexed to biotinylated HRP. $C B$, portion of untransferred gel stained with Coomassie blue. The RB- 8 antigen is the dense band at $125 \mathrm{kDa}$. WGA, strips of nitrocellulose incubated with biotinylated wheat germ agglutinin in the absence ( - ) or presence $(+)$ of $1 \mathrm{M} N$-acetyl glucosamine. Con $A$, strips of nitrocellulose incubated with biotinylated concanavalin $\mathrm{A}$ in the absence $(-)$ or presence $(+)$ of $1 \mathrm{M} \alpha$-methyl mannoside. The RB- 8 antigen is densely labeled with both lectins alone and this labeling is specifically blocked by the appropriate monosaccharide ligand. Molecular weight standards as in Figure 2.

Helix pomatia, and biotinylated lectin from Ricinus communis did not react with the $125 \mathrm{kDa}$ band on parallel nitrocellullose blots (data not shown).

\section{Polyclonal antisera to the $125 \mathrm{kDa}$ antigen replicates the findings with monoclonal RB-8 antibody}

Two polyclonal rabbit antisera were prepared by repeated intradermal injection with gel-purified $125 \mathrm{kDa}$ protein. The resulting antisera are monospecific on immunoblots and react with a $125 \mathrm{kDa} M_{\mathrm{r}}$ protein in olfactory nerve and similarly with a $125 \mathrm{kDa}$ band in forebrain membranes that exclude the olfactory bulb. In mixtures of proteins from the 2 types of membranes separated on 1-dimensional SDS-PAGE, the immunoreactive $125 \mathrm{kDa}$ proteins comigrate (Fig. 4).

In sections of the olfactory epithelium stained with either of the polyclonal antisera, the pattern of labeling in the primary olfactory projection exactly matches that seen with the monoclonal RB-8 antibody (Fig. 5). Indeed, when adjacent sections of either the bulb or the epithelium are compared for the tissue distribution of staining with the monoclonal antibody to polyclonal antiserum, the boundaries between the stained and un-

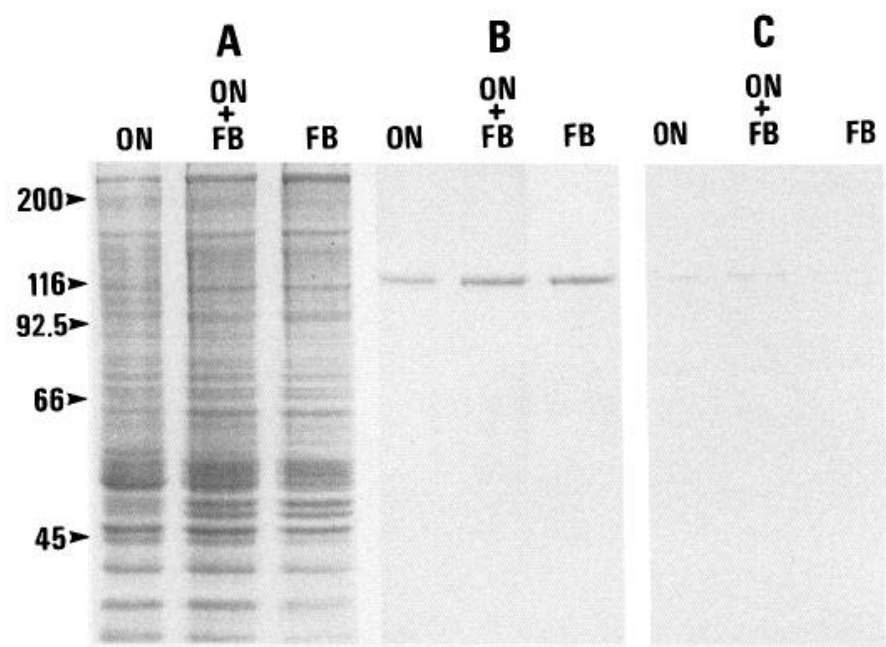

Figure 4. The rabbit antiserum raised against the $125 \mathrm{kDa}$ RB- 8 antigen from whole brain is monospecific and recognizes the $125 \mathrm{kDa}$ protein in olfactory nerve. $A$, Coomassie blue-stained SDS-PAGE gel of roughly equivalent amounts of membrane proteins-about $25 \mu \mathrm{g}$ for each lane-from the olfactory nerve $(O N)$ and from the remainder of the forebrain excepting the bulbs $(F B) . O N+F B$ is a mixture of the 2 types of membranes, and each is present in half the amount of the flanking lanes. $B$ and $C$ are matching gels that were incubated with rabbit antiserum to the $125 \mathrm{kDa}$ protein or with preimmune rabbit serum, respectively. Note the immunoreactive proteins at $125 \mathrm{kDa}$ in both $\mathrm{ON}$ and FB that comigrate in the mixture of the membranes from the 2 sources. This result indicates that there is a substantial degree of immunological cross-reactivity with the antigen in the olfactory nerve. The faint band at $125 \mathrm{kDa}$ seen in blots of ON or FB membranes incubated with the preimmune serum $(C)$ is not the RB-8 antigen. Rather, it is a second $125 \mathrm{kDa}$ brain protein, which can be separated from the RB-8 antigen by 2-dimensional gel electrophoresis (not shown). This artifact varies in intensity depending on the stickiness of different lots of nitrocellulose paper. For example, it is present but much weaker in lanes 1-3 of $C$ in Figure 3. As expected, it is absent from blots of the partially purified or totally pure RB-8 antigen as shown in lanes 4 and 5 of $C$ in Figure 3. Molecular weight standards as in Figure 2.

stained glomeruli in the bulb and between the stained and unstained nerve fascicles in the olfactory epithelium match up precisely.

The virtual identity of the staining patterns with the monoclonal and polyclonal reagents and the reactivity of the antisera with a $125 \mathrm{kDa}$ protein in both olfactory nerve and forebrain indicate a high degree of homology, if not identity, between the RB-8 antigen in the olfactory nerve and that in the remainder of the brain, and verifies our assumption that using whole brain as the starting material for purification of the $125 \mathrm{kDa}$ antigen is a valid approach. The original results, obtained with the monoclonal antibody, could be explained by the differential expression of a single epitope in the 2 zones of the olfactory epithelium. The present results with the antisera suggest that expression of the entire $125 \mathrm{kDa}$ protein is differentially regulated by ventral and dorsal zones of the olfactory epithelium.

\section{Discussion}

Our results demonstrate the isolation and characterization of a protein antigen that is spatially segregated in the primary olfactory projection. We can use these findings to assign a biochemical identity to the RB-8 antigen that is sufficiently detailed to permit its comparison with other neural-specific proteins now and in the future; for example, this knowledge would be useful if the RB-8-like antigen recognized by monoclonal antibody 

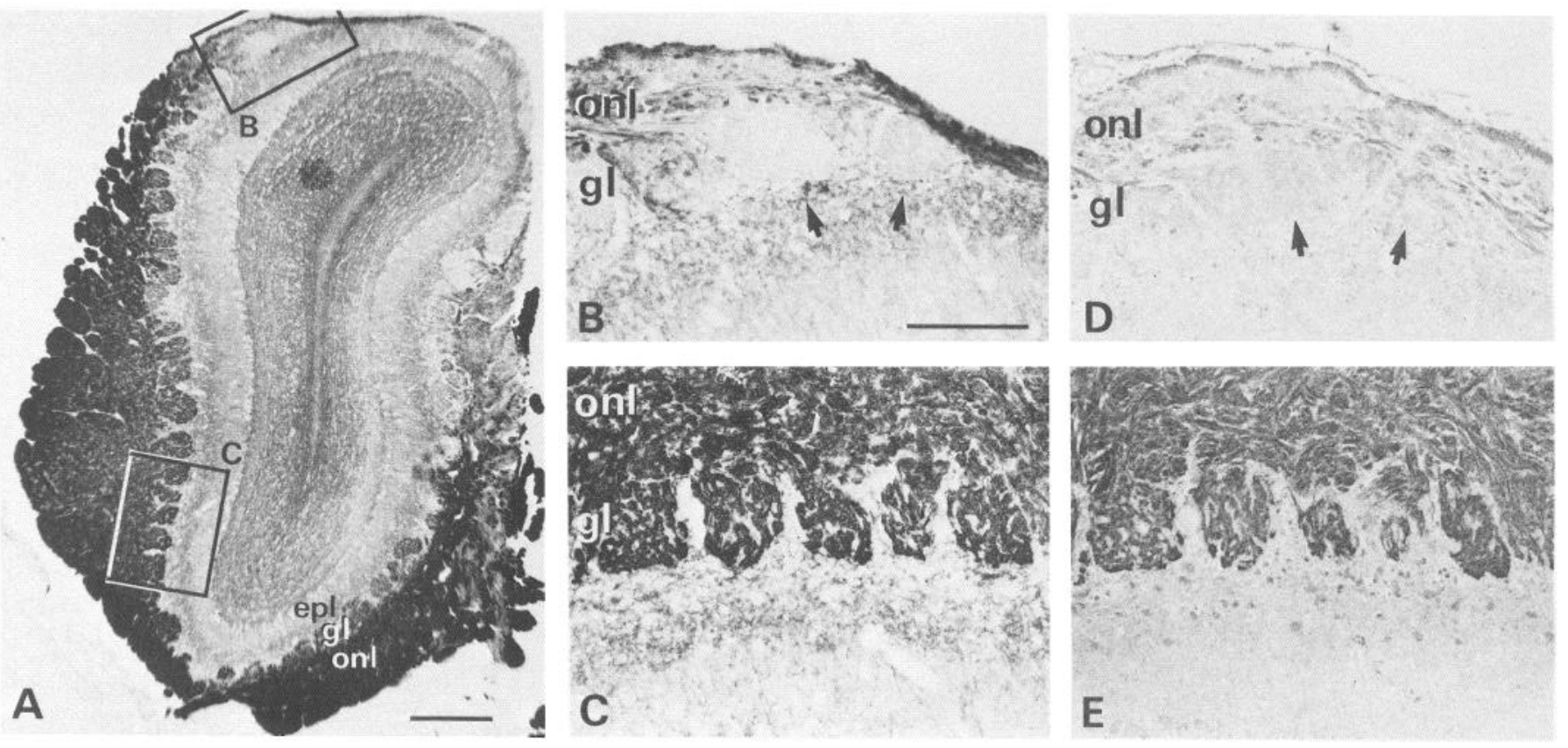

Figure 5. The rabbit antiserum raised against the $125 \mathrm{kDa}$ RB- 8 antigen exactly replicates the staining pattern with the monoclonal antibody RB-8 in the glomerular layer of the bulb. Dorsal is up, medial is to the right. $A$, Low-power photomicrograph of a cryostat section of the bulb stained with the monoclonal RB-8 antibody. Note the differential staining of glomeruli in the ventrolateral and dorsomedial parts of the bulb, as indicated at higher power in $B$ and $C$ for the boxed areas. $D$ and $E$ are taken from an adjacent section stained with the rabbit antiserum to the RB-8 antigen. $D$ corresponds to the same area of the dorsal bulb as in $B$, and the same glomeruli on the 2 sections are unstained (arrows). Likewise, $E$ corresponds to $C$ in the ventrolateral bulb, and the glomeruli are heavily stained. Thus the $125 \mathrm{kDa}$ protein as a whole is spatially restricted in its distribution in the same way as is the epitope recognized by the monoclonal RB-8 antibody. This result also confirms the close homology between the protein purified from whole brain and the spatially restricted antigen in the olfactory nerve. Scale bar in $A, 250 \mu \mathrm{m}$. Scale bar in $B$, $100 \mu \mathrm{m}$; this applies to $B-E$. $e p$, external plexiform layer; $g l$, glomerular layer; onl, olfactory nerve layer.

R4B12 (Mori et al., 1985) is characterized biochemically in deciding whether this antigen is truly homologous with the RB-8 antigen. Moreover, the characterization of the RB-8 antigen has additional implications for the as-yet-unknown function of the protein at the cellular level in olfactory sensory neurons. The identifying features of the RB- 8 antigen reported here include its $\mathrm{NH}_{2}$-terminal amino acid sequence, its exposure on the cell surface, and its character as an integral membrane glycoprotein. Although some of the experiments used antigen purified from whole brain, this form of the antigen is clearly very homologous, if not identical, to the antigen in olfactory nerve, since the polyclonal antisera prepared against whole-brain RB-8 antigen exactly replicate the staining pattern in the olfactory projection seen with the monoclonal RB-8 antibody. That is, the monoclonal antibody and both polyclonal antisera recognize a $125 \mathrm{kDa}$ protein that is restricted to the olfactory axons from ventral olfactory epithelium and their terminals in the glomeruli of the ventral olfactory bulb. Each of the identifying features of the RB- 8 antigen and its functional implication will be discussed.

The $\mathrm{NH}_{2}$-terminal amino acid sequence is apparently novel. There is no significant homology between the 125 kDA RB-8 antigen sequence and the proteins listed in the Protein Sequence Data Base (National Biomedical Research Foundation). The best match is with the $\mathrm{NH}_{2}$-terminal sequence of a kappa light chain designated K1 HUWS, which matches at 7 of the 16 residues ( $44 \%$ homology). In addition, direct comparison with the $\mathrm{NH}_{2}$-terminal sequence of known cell surface antigens whose size approximates $125 \mathrm{kDa}$ shows no homology whatsoever. These antigens include the $120 \mathrm{kDa}$ form of N-CAM (Rougon and Marshak, 1986), E-cadherin/L-CAM/uvomorulin (Gallin et al., 1987; Nagafuchi et al., 1987) and N-cadherin (Shirayoshi et al., 1986). Likewise, there are no areas of evident homology with other mammalian neural cell surface antigens, such as neurotransmitter receptors and ion channels, whose size differs significantly from $125 \mathrm{kDa}$, but whose amino acid sequence has been published in full or in part (Numa et al., 1983; Kubo et al., 1986; Noda et al., 1986; Grenningloh et al., 1987; Rathjen et al., 1987; Scholfield et al., 1987). Since the portion of the RB-8 antigen that has been sequenced is short, this comparison is somewhat limited, but is sufficient to exclude the possibility that the RB-8 antigen is identical to an already sequenced neural cell surface protein. The question of whether the RB- 8 antigen is related to one of these other proteins, and the potential functional implication of such relatedness, requires that the fulllength amino acid sequence of the RB- 8 antigen be determined. This goal would best be achieved through the application of recombinant DNA technology to isolate a cDNA clone corresponding to the RB-8 antigen mRNA. The availability of the monoclonal RB-8 antibody and the polyclonal RB-8 antisera makes cDNA cloning feasible (Young and Davis, 1983).

In addition, the results presented here are useful for distinguishing the RB-8 antigen from other olfactory markers that have not been sequenced. For example, there is a recently described marker in the rat olfactory projection that is recognized by soybean agglutinin and is limited to a subset of olfactory sensory neurons and glomeruli (Key and Giorgi, 1986). The RB-8 antigen is clearly different from this marker because, first, the staining patterns do not match and, second, soybean lectin does not bind to the purified RB- 8 antigen. 
A major remaining challenge with respect to this spatially segregated protein is to define precisely its cellular function in olfactory sensory neurons. The exposure of the RB-8 antigen on the cell surface of olfactory axons and its position as an integral membrane glycoprotein constrain the potential cellular functions of this protein. In the previous paper (Schwob and Gottlieb, 1986), we suggested in broad terms 2 possible roles for the RB-8 antigen in the cell biology of the olfactory axon. First, the RB- 8 antigen may be involved in some aspect of neurotransmitter function that is expressed in a spatially limited subset of olfactory sensory neurons; the transmitter(s) at the olfactory axon-mitral cell synapse is (are) at present unknown. Alternatively, the RB- 8 antigen may function during the development of the primary olfactory projection, for example, by directing or helping to direct axons from the ventral olfactory epithelium to the ventral part of the olfactory bulb where they synapse. The present findings do not eliminate either of these alternatives, but do restrict the range of possible cellular functions within each of the 2 broadly defined alternatives. For example, if the RB-8 antigen is involved in neurotransmission, the protein is unlikely to serve as a synthetic enzyme, since it is exposed on the cell surface. However, the RB-8 antigen could conceivably function as a presynaptic transmitter receptor or as a component of a transmitter-inactivation mechanism. Likewise, for a potential role in the development of the olfactory projection, the RB-8 antigen is suitably placed to contact the surface of other cells, either neurons or glia, or to serve as a receptor for a soluble factor in the environment. Since the RB-8 antigen is exposed on the cell surface, there is an opportunity to discover its functional role using external application of antibody to block function. Antibody-blocking experiments have been used successfully to disrupt several aspects of axonal growth, both in vitro and in vivo (Stallcup and Beasley, 1985; Fischer et al., 1986; Chang et al., 1987; Rathjen et al., 1987), and to block neurotransmission at the neuromuscular junction (Peper et al., 1981). For example, antibodies directed against N-CAM have been shown to disrupt fasciculation of axons in tissue culture (Rutishauser et al., 1978), the formation of neuromuscular contacts in culture (Rutishauser et al., 1983), and the course of growing axons in the whole animal (Fraser et al., 1984). Experiments of this sort, using the monoclonal RB-8 antibody or the polyclonal antisera, may provide further insight into the cellular function of the RB-8 antigen in the primary olfactory projection and elsewhere in the brain.

\section{References}

Adrian, E. D. (1953) Sensory messages and sensations: The response of the olfactory organs to different smells. Acta Physiol. Scand. 29: 5-14.

Adrian, E. D. (1954) The bases of sensation: Some recent studies of olfaction. Br. Med. J. 1: 289-290.

Bennett, V. (1985) The membrane cytoskeleton of human erythrocytes and its implications for more complex cells. Annu. Rev. Biochem. 54: 273-304.

Burden, S. J., R. L. dePalma, and G. S. Gottlesman (1983) Cross linking of proteins in acetylcholine receptor-rich membranes: Associations between the $\beta$-subunit and the $43 \mathrm{Kd}$ subsynaptic protein. Cell 35: 687-692.

Chang, S., F. G. Rathjen, and J. A. Raper (1987) Extension of neurites on axons is impaired by antibodies against specific neural cell surface glycoproteins. J. Cell Biol. 104: 355-362.

Fischer, G., V. Kühnemund, and M. Schachner (1986) Neurite outgrowth patterns in cerebellar microexplant cultures are affected by antibodies to the cell surface glycoprotein L1. J. Neurosci. 6: 605612.
Fraser, S. E., B. A. Murray, C.-M. Chuong, and G. M. Edelman (1984) Alteration of the retinotectal map in Xenopus by antibodies to neural cell adhesion molecules. Proc. Natl. Acad. Sci. USA 81: 4222-4226.

Fujita, S. C., K. Imamura, and K. Obata (1985) Subclasses of olfactory receptor cells and their segregated central projections demonstrated by a monoclonal antibody. Brain Res. 326: 192-196.

Gallin, W. J., B. C. Sorkin, G. M. Edelman, and B. A. Cunningham (1987) Sequence analysis of a cDNA clone encoding the liver cell adhesion molecule, L-CAM. Proc. Natl. Acad. Sci. USA 84: 2808 2812.

Gonzales, F., A. I. Farbman, and R. C. Gesteland (1985) Cell and explant culture of olfactory chemoreceptor cells. J. Neurosci. Methods 14: 77-90.

Greeningloh, G., A. Rienitz, B. Schmitt, C. Methfessel, M. Zensen, K. Beyreuther, E. D. Gundelfinger, and H. Betz (1987) The strychninebinding subunit of the glycine receptor shows homology with nicotinic acetylcholine receptors. Nature 328: 215-220.

Jourdan, F., A. Duveau, L. Astic, and A. Holley (1980) Spatial distribution of $\left[{ }^{14} \mathrm{C}\right] 2$-deoxyglucose uptake in the olfactory bulbs of rats stimulated with two different odours. Brain Res. 188: 139-154.

Key, B., and P. P. Giorgi (1986) Soybean agglutinin binding to the olfactory systems of the rat and mouse. Neurosci. Lett. 69: 131-136.

Kubo, T., K. Fukada, A. Mikami, A. Maeda, H. Takahashi, M. Mishina, T. Haga, K. Haga. A. Ichiyama, K. Kengawa, M. Kojima, H. Matsuo, T. Hirose, and S. Numa (1986) Cloning, sequence and expression of complementary DNA encoding the muscarinic acetylcholine receptor. Nature 323: 411-416.

Laemmli, U. K. (1970) Cleavage of structural proteins during the assembly of the head of bacteriophage T4. Nature 227: 680-685.

Lancet, D., J. S. Kauer, C. A. Greer, and G.M. Shepherd (1981) High resolution 2-deoxyglucose localization in olfactory epithelium. Chem. Senses 6: 343-349.

Lancet, D., C. A. Greer, J. S. Kauer, and G. M. Shepherd (1982) Mapping of odor-related neuronal activity in the olfactory bulb by high-resolution 2-deoxyglucose autoradiography. Proc. Natl. Acad. Sci. USA 79: 670-674.

Lemmon, V., E. Staros, H. E. Perry, and D. I. Gottlieb (1982) A monoclonal antibody which binds to the surface of chick brain cells and myotubes: Cell selectivity and properties of the antigen. Dev. Brain Res. 3: 349-360.

Levine, J., and M. Willard (1981) Fodrin: Axonally transported polypeptides associated with the internal periphery of many cells. J. Cell Biol. 90: 631-643.

Mackay-Sim, A., P. Shaman, and D. G. Moulton (1982) Topographic coding of olfactory quality: Odorant-specific patterns of epithelial responsivity in the salamander. J. Neurophysiol. 48: 584-596.

Monroe, D. (1985) The solid-phase enzyme-linked immunospot assay: Current and potential applications. BioTechnology 3: 222-229.

Mori, K., S. C. Fujita, K. Imanura, and K. Obata (1985) Immunohistochemical study of subclasses of olfactory nerve fibers and their projections to the olfactory bulb in the rabbit. J. Comp. Neurol. 242: 214-229.

Mozell, M. M. (1964) Olfactory discrimination: Electrophysiological spatiotemporal basis. Science 143: 1336-1337.

Nagafuchi, A., Y. Shirayoshi, K. Okazaki, Y. Yasuda, and M. Takeichi (1987) Transformation of cell adhesion properties by exogenously introduced E-cadherin cDNA. Nature 329: 341-343.

Noda, M., T. Ikeda, T. Kayano, H. Suzuki, H. Takeshima, M. Kurasaki, H. Takahashi and S. Numa (1986) Existence of distinct sodium channel messenger RNA's in rat brain. Nature 320: 188-192.

Numa, S., M. Noda, H. Takahashi, M. Toyosato, Y. Furutani, and S. Kikyotani (1983) Molecular structure of the nicotinic acetylcholine receptor. Cold Spring Harb. Symp. Quant. Biol. 48: 57-69.

O'Farrell, P. H. (1975) High resolution two-dimensional electrophoresis of proteins. J. Biol. Chem. 250: 4007-4021.

Peper, K., R. Sterz and R. J. Bradley (1981) Effects of drugs and antibodies on the post-synaptic membrane of the neuromuscular junction. Ann. NY Acad. Sci. 377: 519-543.

Rathjen, F. G., J. M. Wolff, R. Frank, F. Bonhoeffer, and U. Rutishauser (1987) Membrane glycoproteins involved in neurite fasciculation. $J$. Cell Biol. 104: 343-353.

Rougon, G., and D. R. Marshak (1986) Structure and immunological characterization of the amino-terminal domain of mammalian neural cell adhesion molecules. J. Biol. Chem. 261: 3396-3401.

Rutishauser U., W. E. Gall, and G. M. Edelman (1978) Adhesion 
among neural cells of the chick embryo. IV. Role of the cell surface molecule CAM in the formation of neurite bundles in cultures of spinal ganglion. J. Ccll Biol. 79: 382-393.

Rutishauser, U., M. Grumet, and G. M. Edelman (1983) Neural cell adhesion molecule mediates initial interactions between spinal cord neurons and muscle cells in culture. J. Cell Biol. 97: 145-152.

Scholfield, P. R., M. G. Darlison, N. Fujita, D. R. Burt, F. A. Stephenson, H. Rodriguez, L. M. Rhee, J. Ramachandran, V. Reale, T. A. Glencorse, P. H. Seeburg, and E. A. Barnard (1987) Sequence and functional expression of the $\mathrm{GABA}_{\mathrm{A}}$ receptor shows a ligand-gated receptor super-family. Nature 328: 221-227.

Schwob, J. E., and D. I. Gottlieb (1986) The primary olfactory projection has two chemically distinct zones. J. Neurosci. 6: 3393-3404.

Schwob, J. E. and D. I. Gottlieb (1987) Purification and characterization of an antigen that is spatially segregated in the primary olfactory projection. Soc. Neurosci. Abstr. 13: 1635 .

Schwob, J. E., N. B. Farber, and D. I. Gottlieb (1986) Neurons of the olfactory epithelium in adult rats contain vimentin. J. Neurosci. 6 : 208-217.

Shirayoshi, Y., K. Hatta, M. Hosoda, S. Tsunasawa, F. Sakiyama, and M. Takeichi (1986) Cadherin cell adhesion molecules with distinct binding specificities share a common structure. EMBO J. 6:24852488.

Skeen, L. C. (1977) Odor-induced patterns of deoxyglucose consumption in the olfactory bulb of the tree shrew, Tupaia glis. Brain Res. 124: 147-153.

Smith, P. K., R. I. Krohn, G. T. Hermanson, A. K. Mallia, F. H. Garnter, M. D. Provenzano, E. K. Fujimoto, N. M. Goeke, B. J. Olson, and D. C. Klenk (1985) Measurement of protein using bicinchoninic acid. Anal. Biochem. 150:73-85.

Stallcup, W. B., and L. L. Beasley (1985) Involvement of the nerve growth factor-inducible large external glycoprotein (NILE) in neurite fasciculation in primary cultures of rat brain. Proc. Natl. Acad. Sci. USA 82: $1276-1280$.

Steck, T. L., and J. Yu (1973) Selective solubilization of proteins from red cell membranes by protein perturbants. J. Supramol. Struct. 1 : 220-232.

Stewart, W. B., J. S. Kauer, and G. M. Shepherd (1979) Functional organization of rat olfactory bulb analyzed by the 2-deoxyglucose method. J. Comp. Neurol. 185: 715-734.

Thommesen, G. (1978) The spatial distribution of odour induced potentials in the olfactory bulb of char and trout (Salmonidae). Acta Physiol. Scand. 102: 205-217.

Thommesen, G., and K. B. Doving (1977) Spatial distribution of the EOG in the rat; a variation with odour quality. Acta Physiol. Scand. 99: 270-280.

Towbin, H., T. Staehlin, and J. Gordon (1979) Electrophoretic transfer of proteins from polyacrylamide gels to nitrocellulose shects: Procedure and some applications. Proc. Natl. Acad. Sci. USA 76: 43504354.

Tuszynski, G. P., L. Knight, J. R. Piperno, and P. N. Walsh (1980) A rapid method for removal of $\left[{ }^{125} \mathrm{I}\right]$ iodide following iodination of protein solution. Anal. Biochem. 106: 118-122.

Wessel, D., and U. I. Flugge (1984) A method for the quantitative rcovery of protein in dilute solution in the presence of detergents and lipids. Anal. Biochem. 138: 141-143.

Wiedenmann, B., K. Lawley, C. Grund, and D. Branton (1985) Solubilization of proteins from bovine brain coated vesicles by protein perturbants and Triton X-100. J. Cell Biol. 101: 12-18.

Young, R. A., and R. W. Davis (1983) Efficient isolation of genes by using antibody probes. Proc. Natl. Acad. Sci. USA 80: 1194-1198. 